\title{
ORIENTATION OF THE VALUES OF THE TEACHING PROFESSION FOR UNDERGRADUATE STUDENTS MAJORING IN PHYSICAL EDUCATION
}

\author{
Phung Xuan Dung ${ }^{i}$ \\ Ha Noi University \\ of Physical Education and Sports, \\ Vietnam
}

\begin{abstract}
:
The research was conducted to determine the current situation of undergraduate students' teaching career value orientation, which will serve as the foundation for suggesting several educational solutions that will orient them with a teaching career. According to the poll, most students majoring in Physical Education have a fairly good impression of the values of the teaching profession; they highly value social values, followed by moral values, and lastly a group of new values. However, the majority of students still have a poor perception of the teaching career. This demonstrates the misconception of Physical Education major students about the role and significance of the teaching profession, as well as teachers' considerable contributions to society.
\end{abstract}

Keywords: orientation, values of the teaching profession, students, physical education

\section{Introduction}

All human activities are guided by value orientation, which determines personality development. To be capable of providing more valuable benefits for society, individuals in any job need to have a strong professional value orientation.

We live in an age of multicultural integration, which coincides with the rapid advancement of science and technology. As a result, each profession's value scale system is shifting and shaking at times. Hence, to avoid being backwards and disintegrated in society's evolution, each person must make a reasonable effort, equip himself with a strong foundation of knowledge, and determine values suited for his profession. It can be said that vocational orientation for students is an important issue that needs to be paid attention to motivate them to study, practice and cultivate so that when they graduate, they can meet the requirements of their future profession as well as of society.

i Correspondence: phungxuandung@gmail.com 
Universities have steadily improved their teaching material and methodologies, as well as their organizational and administration approaches, over time, but they have not given enough attention to the issue of career value orientation for students. As a result, answering the question, "What are the career values that students aspire to?" is challenging. And what are the most important career values for students? With careful consideration, the authors decided to research on: "Orientation of the values of the teaching profession for undergraduate students majoring in Physical Education".

The objective of this study is to find out the present situation of undergraduate students' teaching career value orientation, which will serve as the foundation for developing educational solutions to help students better understand the teaching career value.

Research subject: Value orientation of the teaching profession.

Research object: 342 undergraduate students majoring in Physical Education; in which 172 first-year students and 170 fourth-year students.

\section{Methodology}

Analyzing and synthesizing documents, interviewing and Statistical method were employed.

\subsection{Instruments}

\section{a. Questionnaire}

The researcher developed a questionnaire based on the theoretical foundation (literature review) to get general views on the orientation of the teaching profession values among Physical Education majors.

\section{b. Survey}

In order to improve the impartiality and accuracy of the data obtained, the research team created an interview form that was used to interview students directly. In order to evaluate the data, the scales were agreed as follow: distance $=($ Maximum - Minimum $) / \mathrm{n}$ $=(5-1) / 5=0.8$. The scales: $1.00-1.80$ : Level 1 (strongly disagree/ Important); $1.81-2.60$ : Level 2 (Disagree/ not important); 2.61 - 3.40: level 3 (Neutral); 3.41 - 4.20: level 4 (agree / Important); 4.21 - 5.00: level 5 (strongly agree/ Important).

\section{c. Mathematical Statistics}

The data were analyzed using SPSS for Windows software.

\subsection{Period of Implementation}

August 2020 until December 2020. 


\section{Research Results and Discussion}

\subsection{Literature Review}

a. Value Concept, Value Orientation, Vocational Value, and Teaching Profession Value Orientation

The article summarizes the following concepts based on the theoretical analysis of the scientists and educational dictionaries including (Hoang Anh, 2007), (Tran Thi Chanh, 2003), (Law on Education, 2005), (Pham Thanh Nghi, 2013), (Le Duc Phuc, 1992), (Dao Hien Phuong, 1991), (Nguyen Thac, 2014), Tran Trong Thuy, 1993), (Nguyen Huy Tuyen, 2006), and (Thai Duy Tuyen, 2007).

Values are things that are essential, valuable, and significant to the subject (individuals, groups, and society), representing the subject-object connection, and can be reviewed and altered according to the requirements and interests of the socio-historical situations. Also, human personality is linked to a value factor.

Value orientation is a standard value system that conforms to societal requirements and is perceived, evaluated, and selected by individuals (or groups) based on their aspirations and desires. It tends to shape and regulate human behavior and actions, as well as individual personality traits.

Vocational value is what is truly significant, especially for professional activities, and it is beneficial in terms of completely improving the quality of the professional workforce.

The teaching profession value orientation is a subjective and selective reflection of the teaching profession values in the teachers' beliefs and psychology, as well as a process of determining the subject's teaching profession values based on feelings, attitudes, and positivity in professional activities (Thai Duy Tuyen, 2007).

In terms of the school's training objective, this topic is essentially the process of instilling the educator's personality in the undergraduate students. Personality is defined as the degree to which the teacher's value scale and personal value orientation align with the community's and society's value scale and value orientation. The article divides the teaching profession's value system into the following categories:

- Social values in education: they have shared values in education, such as moral views and principles, that are accepted by the majority to preserve a society's continuance.

- Ethical values in education: they are distinct ethical standards of the teaching profession that serve as a measure of the qualities that make a good teacher.

- New educational values: In the current globalization trend, a professional teacher must consider both conventional and international ideals such as dynamism, realism, enterprising spirit, sense of responsibility. The reason is that we are living in the age of globalization and great competitiveness, thus professional values should be integrated on a worldwide scale. 


\section{b. The Current Situation of Undergraduate Students' Value Orientation toward the Teaching Profession}

- Undergraduate Students' Perception of the Importance of Teaching Profession Values

A survey of 342 Physical Education majors was conducted, with the results shown in Table 1.

Table 1: Survey results on English undergraduate students' perceptions of the importance of teaching profession values

\begin{tabular}{|c|c|c|c|c|c|c|}
\hline \multirow[t]{2}{*}{$\begin{array}{l}\text { Types of } \\
\text { values }\end{array}$} & \multirow[t]{2}{*}{ Item } & \multirow[t]{2}{*}{ Teaching professional values } & \multicolumn{2}{|c|}{$\begin{array}{c}\text { Important and } \\
\text { highly } \\
\text { important }\end{array}$} & \multirow{2}{*}{$\begin{array}{l}\text { Mean } \\
\text { score } \\
(\mathrm{M})\end{array}$} & \multirow[t]{2}{*}{ Rank } \\
\hline & & & $\mathbf{N}$ & $(\%)$ & & \\
\hline \multirow{8}{*}{ Social } & 1 & $\begin{array}{l}\text { Contributing to the construction and defense of } \\
\text { the homeland }\end{array}$ & 101 & 29.5 & 2.91 & 17 \\
\hline & 2 & Educating good citizens for society & 310 & 90.6 & 4.23 & 2 \\
\hline & 3 & $\begin{array}{l}\text { Reproducing and increasing social labor } \\
\text { productivity }\end{array}$ & 155 & 45.3 & 3.12 & 13 \\
\hline & 4 & $\begin{array}{l}\text { Educating youngsters about national pride and } \\
\text { patriotism }\end{array}$ & 295 & 86.2 & 4.09 & 4 \\
\hline & 5 & $\begin{array}{l}\text { Promoting economic, social, and cultural } \\
\text { development }\end{array}$ & 167 & 48.8 & 3.56 & 10 \\
\hline & 6 & $\begin{array}{l}\text { Raising people's intelligence, training human } \\
\text { resources, and nurturing talents }\end{array}$ & 342 & 100 & 4.43 & 1 \\
\hline & 7 & $\begin{array}{l}\begin{array}{l}\text { Encouraging each individual in self- } \\
\text { improvement }\end{array} \\
\end{array}$ & 135 & 39.5 & 3.06 & 14 \\
\hline & & Overall & & & 3.63 & \\
\hline \multirow{8}{*}{ Ethical } & 8 & Constructing a profoundly humane society & 213 & 62.3 & 3.76 & 8 \\
\hline & 9 & $\begin{array}{l}\text { Educating students on how to live fairly and } \\
\text { equitably, as well as how to respect others }\end{array}$ & 134 & 39.2 & 2.96 & 16 \\
\hline & 10 & $\begin{array}{l}\text { Ingraining in students a sense of teacher } \\
\text { respect, rectitude, and decorum }\end{array}$ & 298 & 87.2 & 4.21 & 3 \\
\hline & 11 & $\begin{array}{l}\text { Assisting pupils to develop a sense of dignity } \\
\text { and personal identity. }\end{array}$ & 190 & 55.6 & 3.47 & 11 \\
\hline & 12 & $\begin{array}{l}\text { Encouraging people to live with tolerance, } \\
\text { altruism, and kindness }\end{array}$ & 95 & 27.8 & 2.79 & 18 \\
\hline & 13 & $\begin{array}{l}\text { Encouraging pupils' hard work, eagerness to } \\
\text { learn, and their community spirit. }\end{array}$ & 69 & 20.1 & 2.52 & 20 \\
\hline & 14 & Forming beautiful personalities & 288 & 84.2 & 3.95 & 6 \\
\hline & & Overall & & & 3.38 & \\
\hline \multirow{4}{*}{ New } & 15 & $\begin{array}{l}\text { Cultivating dynamism, creativity, and acuity in } \\
\text { students }\end{array}$ & 211 & 61.7 & 3.86 & 7 \\
\hline & 16 & $\begin{array}{l}\text { Nurturing in students a sense of personal } \\
\text { responsibility }\end{array}$ & 86 & 25.1 & 2.68 & 19 \\
\hline & 17 & $\begin{array}{l}\text { Forming a competitive and entrepreneurial } \\
\text { spirit among students }\end{array}$ & 55 & 16.1 & 2.46 & 21 \\
\hline & 18 & $\begin{array}{l}\text { Fostering students' belief in life, truth, and } \\
\text { rationality }\end{array}$ & 210 & 61.4 & 3.74 & 9 \\
\hline
\end{tabular}


FOR UNDERGRADUATE STUDENTS MAJORING IN PHYSICAL EDUCATION

\begin{tabular}{|c|c|l|c|c|c|c|}
\hline \hline 19 & $\begin{array}{l}\text { Empowering the younger generation to explore } \\
\text { and discover the truth }\end{array}$ & 127 & 37.1 & 3.04 & 15 \\
\cline { 2 - 7 } & 20 & $\begin{array}{l}\text { Inspiring the next generations with a spirit of } \\
\text { self-improvement and triumph against } \\
\text { adversity }\end{array}$ & 175 & 51.2 & 3.28 & 12 \\
\cline { 2 - 7 } & Motivating youngsters' dreams and ambitions & $\mathbf{2 7 9}$ & $\mathbf{8 1 . 6}$ & $\mathbf{3 . 9 8}$ & $\mathbf{5}$ \\
\hline
\end{tabular}

Table 1 indicates that English undergraduate students rate 11 items (52.38\%) as very important and important $(M>3.4)$ for the teaching profession; in which there are 03 items $(14.29 \%)$ that students perceive as very important $(\mathrm{M}>4.2)$, which are raising people's intelligence, training human resources, and nurturing talents; educating good citizens for society; ingraining in students a sense of teacher respect, rectitude, and decorum; and 08 items (38.10\%) are rated as important. However, English majors rate 10 items (47.62 percent) as neutral and unimportant $(\mathrm{M}<3.4)$ with 02 items perceived as unimportant $(1.81<\mathrm{M}<2.60)$, which are to encourage pupils' hard work, eagerness to learn, their community spirit; form a competitive and entrepreneurial spirit among students; and 08 items (38.10\%) perceived with a neutral attitude.

Surprisingly, the item "Empowering the younger generation to explore and discover the truth", which is at the core of the entire teaching process, is not highly regarded (15th with the average score: $M=3.04$, neutral level). It reveals that undergraduate students have a limited understanding of the nature of teaching activities. Today, the teaching concept is no longer about "pouring knowledge" to learners, but inspiring, raising awareness, and motivating learners to acquire knowledge on their own. As a well-known educational psychologist put it this way, "The mediocre teacher tells. The good teacher explains. The superior teacher demonstrates. The great teacher inspires" William Arthur Ward.

Among the three groups of teaching values, the students most appreciate the social value group with an average value of 3.63 scores, followed by the moral values, and finally the group of new values with an average score of 3.38 and 3.29 respectively, at the normal level. Chart 1 shows the comparison of the students' perceptions on the importance of 3 groups of teaching profession values.

Figure 1 may be used to debate whether or not it is because the social values of the teaching profession are so universal that the whole society automatically acknowledges it while forgetting that the other groups of values are equally essential. Because students are a part of society, they are not an exception to that stereotype. As a result, it is understandable that the social values of the teaching profession are the highest valued, as seen in Figure 1. 


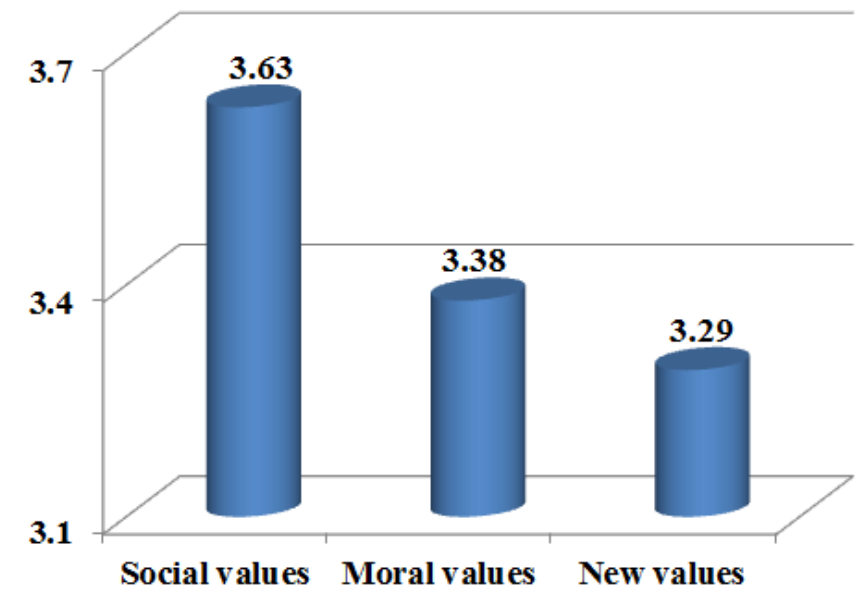

Figure 1: A comparison of survey results on the English students' perceptions towards the importance of three groups of teaching profession values

The teaching profession's new value group has the lowest rating. This can be explained by the impact of environmental factors on personality formation and development. Because most students reside in rural regions, they do not realize the importance of being dynamic, creative, and keen learners with a high sense of personal responsibility, and the desire for the truth. They are also unaware of the scientific, creative, and aesthetic aspects of the teaching profession while these elements play a vital role in an individual's success.

The findings of the survey of the students in the first and fourth years are compared using two independent samples T-tests, as shown in Table 2.

Table 2: A comparison of survey results between the perceptions of the freshmen and seniors towards three groups of teaching profession values

\begin{tabular}{|l|c|c|c|c|c|}
\hline Types of students & \multicolumn{2}{|c|}{ Freshmen } & \multicolumn{2}{c|}{ Seniors } & \multirow{2}{*}{ Sig } \\
\cline { 2 - 6 } Value groups & Mean & SD & Mean & SD & \multirow{2}{*}{ Sig } \\
\hline Social & 3.58 & 0.8 & 3.68 & 1.06 & 0.69 \\
\hline Moral & 3.36 & 1.12 & 3.40 & 1.26 & 0.21 \\
\hline New & 3.15 & 1.03 & 3.44 & 1.12 & 0.01 \\
\hline
\end{tabular}

With a significance level $\alpha=0.05$, it is easy to find out a difference between the freshmen and senior students towards the set of new teaching values. The following is an explanation.

In the first year at university, they are not completely aware of the teaching profession, underestimate the role of the "pedagogical" profession, and focus solely on their expertise. Besides, they haven't had access to pedagogy theory courses like "Teaching Theory," so they do not know the pedagogical profession's hard work and high standards. 


\section{- The Perceptions of English Major Students about the Teaching Profession}

It should be accepted that many individuals in society respect and cherish the teaching profession as well as the values it contributes to society. Do students majoring in Physical Education have a realistic understanding of the teaching values? To find out, the researchers provided 16 positive and negative comments for students to self-assess about teaching careers. Table 2 shows the survey results of 342 students majoring in Physical Education.

Table 2: Perceptions of English major students about the teaching profession

\begin{tabular}{|c|c|c|c|c|c|c|}
\hline \multirow[t]{2}{*}{ Types } & \multirow[t]{2}{*}{ Item } & \multirow[t]{2}{*}{ Perceptions of the teaching profession } & \multicolumn{2}{|c|}{$\begin{array}{l}\text { Extremely agree } \\
\text { and agree }\end{array}$} & \multirow[t]{2}{*}{ Mean } & \multirow[t]{2}{*}{ Rank } \\
\hline & & & $\mathbf{N}$ & $\%$ & & \\
\hline \multirow{9}{*}{$\sum_{\substack{D \\
0}}^{0}$} & 1 & A job that is greatly regarded & 321 & 93.86 & 4.12 & 3 \\
\hline & 2 & A job that the state truly cares about & 145 & 42.4 & 2.88 & 13 \\
\hline & 3 & A pure and great career & 309 & 90.35 & 4.02 & 4 \\
\hline & 4 & A noble career & 338 & 98.83 & 4.30 & 1 \\
\hline & 5 & A scientific and creative job & 216 & 63.16 & 3.14 & 10 \\
\hline & 6 & A job of professional brainwork & 113 & 33.04 & 2.86 & 14 \\
\hline & 7 & $\begin{array}{l}\text { A job with a high volume and a } \\
\text { long working day }\end{array}$ & 85 & 24.85 & 2.62 & 16 \\
\hline & 8 & $\begin{array}{l}\text { A job that requires a high sense of } \\
\text { responsibility and discipline }\end{array}$ & 280 & 81.87 & 3.86 & 6 \\
\hline & & Overall & & & 3.45 & \\
\hline \multirow{9}{*}{ 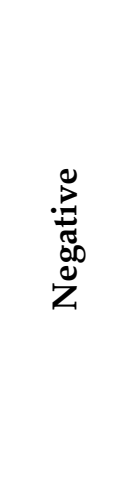 } & 9 & A thankless job & 257 & 75.15 & 3.36 & 9 \\
\hline & 10 & A job that the state gives little thought to & 197 & 57.6 & 3.13 & 11 \\
\hline & 11 & A job that is becoming commercialized & 98 & 28.65 & 2.81 & 15 \\
\hline & 12 & An ordinary job like the others & 190 & 55.56 & 3.06 & 12 \\
\hline & 13 & A job that is repetitive and boring & 269 & 78.65 & 3.60 & 8 \\
\hline & 14 & A job with a lot of unoccupied time & 321 & 93.86 & 4.22 & 2 \\
\hline & 15 & A job that is self-employed as a freelancer & 292 & 85.38 & 3.98 & 5 \\
\hline & 16 & $\begin{array}{l}\text { A job that is not worried about } \\
\text { substandard items affecting its work }\end{array}$ & 269 & 78.65 & 3.84 & 7 \\
\hline & & Overall & & & 3.49 & \\
\hline
\end{tabular}

The statistics show that students generally agree and strongly agree on the following views about teaching: "A job that is greatly regarded", "A pure and great career," "A noble job," "A job that requires a high sense of responsibility and discipline". This demonstrates that English majors still have high regard for teachers, despite widespread criticism, as well as the harmful impacts of the market economy and the deterioration of societal morals. Hence, it is not unsurprising when they do not regard the teaching profession as "an ordinary occupation like any other" because they appreciate the honorable and pure quality of the profession.

It is widely admitted that teaching is an intrinsically respectable, noble, and pure career in society, one in which people regard teachers to be revolutionary warriors. The belief stems from a tradition of studiousness and a regard for human morality. A teacher 
is believed as the one who ingrains morals, spreads knowledge and cultural understanding. Therefore, teachers are adored and respected in every country, especially Vietnam. It is clearly shown by various well-known proverbs: "Father gives you a life, but the quality of that life is determined by your teachers", "Everything can be gained when you have a right teacher", "One word is a teacher; half a word is still a teacher", and so on. Hence, it can be said that these beautiful concepts and studious traditional virtues are deeply rooted in each person's consciousness. As a result, undergraduate students also agree with society's viewpoints. However, they still do not recognize the government's involvement in the teaching profession, even though he frequently refers to the slogans: "Education and training is the first national policy," "Investment in education is the first priority for socio-economic development". Furthermore, pedagogical students also appreciate the nature and qualities of educational activity, emphasizing that it is "A job that requires a high sense of responsibility and discipline".

However, despite the positive remarks, the majority of students are not optimistic about a teaching career, believing it to be "A thankless job," "A job that is repetitive and boring". Besides, the students hold unrealistic beliefs on pedagogical careers, involving "A job that is self-employed as a freelancer, "A job with a lot of unoccupied time", "A job that is not worried about substandard items affecting its work". This is a very concerning finding. The perception leads us to conclude that the students who prepare to be teachers assume teaching as a low-risk, low-stress career. As a result, when they confront reality, they are likely to be "disillusioned," possibly lessening their interest in the teaching profession.

It is even more worrying when the majority of youngsters are unaware that teaching is a form of " $A$ job of professional brainwork", although experts and educators have determined that teaching is a difficult and unique type of job that includes both mental and physical effort.

The comparison of the two groups (positive and negative comments) reveals that most undergraduate students remain unfavorable feelings towards the teaching profession. The results indicate students' misperception about the role and significance of teaching careers, as well as teachers' important contributions to society. As a result, the orientation of vocational values for undergraduates is a necessary and practical activity. Even when the "positive" group has a lower overall score than the "negative" group, their difference is not considerable, which indicates that the students are merely conscious of a small portion of the teaching profession's positive aspects. In general, society always appreciates and honors the teaching profession. No one can deny the importance of education in social development, especially teachers, who make a significant contribution to our goals. Future teachers, in particular, are believed to be more conscious of their enormous responsibilities; nonetheless, it is unfortunate when the fact shows that undergraduate students are not concerned about the career values and refer to teaching as an uninteresting profession. 


\section{Conclusion}

The majority of Physical Education majors have a pretty good understanding of the teaching profession's values. However, most students are not optimistic about being a teacher and have negative thinkings about several career aspects.

\section{Conflict of Interest Statement}

The author declares no conflicts of interest.

\section{About the Author}

Phung Xuan Dung has been Institutional Council's chairman of Hanoi University of Physical Education and Sports, Vietnam. His major is short-distance running.

\section{References}

Hoang Anh (2007), The current situation of moral value orientation of pedagogical students in Ho Chi Minh City, Master's thesis in Psychology, Ho Chi Minh City University of Education

Tran Thi Chanh (2003), Value orientation of teaching profession of students at Ha Nam Pedagogical College, Hanoi National University of Education.

Duong Tu Dam (1996), Value orientation of young students in the innovation in Vietnam, PhD. Thesis on Philosophical Science, Hanoi

President of the Socialist Republic of Vietnam (2005), Law on Education, National Political Publishing House, Hanoi.

Nguyen Thi Mai Lan (2008), Personality values orientation of high school pupils showing in learning activities, Journal of Psychology (11)

Nguyen Van Le (1978), Education of professional attitudes for pedagogical students in the process of teacher training, PhD thesis, Hanoi.

Pham Thanh Nghi (2013), Psychology of Education, Publishing House of Vietnam National University, Hanoi.

Dao Thi Oanh (2005), Research on the value orientation of high school students in the current period, Journal of Psychology (8)

Le Duc Phuc (1992), Values and Value Orientation, Educational Research (12)

Dao Hien Phuong (1991), Value orientation - a necessity, Educational Research (2) p.23.

Nguyen Thac (editor) (2014), University Pedagogical Psychology, Pedagogical University Publishing House.

Trinh Thi Thuan (1995), Understanding some manifestations of vocational value orientation in teaching the students at Viet Bac University of Education, Scientific Essay 5.07.03, Hanoi

Tran Trong Thuy (1993), Values, value orientation and personality, Educational Research, (7), p.11 
Nguyen Huy Tuyen (2006), Value orientation of teaching profession of the students at Quang Tri Pedagogical College, Master's Thesis in Psychology, Hanoi

Thai Duy Tuyen (2007), Vietnamese educational philosophy, Pedagogical University Publishing House, Hanoi.

Authors will retain the copyright of their published articles agreeing that a Creative Commons Attribution 4.0 International License (CC BY 4.0) terms will be applied to their work. Under the terms of this license, no permission is required from the author(s) or publisher for members of the community to copy, distribute, transmit or adapt the article content, providing a proper, prominent and unambiguous attribution to the authors in a manner that makes clear that the materials are being reused under permission of a Creative Commons License. Views, opinions and conclusions expressed in this research article are views, opinions and conclusions of the author(s). Open Access Publishing Group and European Journal of Physical Education and Sport Science shall not be responsible or answerable for any loss, damage or liability caused in relation to/arising out of conflict of interests, copyright violations and inappropriate or inaccurate use of any kind content related or integrated on the research work. All the published works are meeting the Open Access Publishing requirements and can be freely accessed, shared, modified, distributed and used in educational, commercial and non-commercial purposes under a Creative Commons attribution 4.0 International License (CC BY 4.0). 